\title{
Pharmacology of the Effects of Bradykinin, Serotonin, and Histamine on the Release of Calcitonin Gene-related Peptide from C-Fiber Terminals in the Rat Trachea
}

\author{
Xiao-Ying Hua and Tony L. Yaksh \\ Department of Anesthesiology, University of California at San Diego, La Jolla, California 92093-0818
}

The effects of inflammatory substances, bradykinin (BK), 5-HT, and histamine (HIS), on the release of calcitonin generelated peptide (CGRP) from the peripheral terminals of sensory afferents in the rat trachea were examined ex vivo. With intralumenal perfusion, the isolated rat trachea displays low but measurable secretion of CGRP (32 $\pm 4.6 \mathrm{fmol} / 10 \mathrm{~min}$ fraction). The addition of BK $\left(10^{-6}\right.$ to $\left.10^{-4} \mathrm{M}\right)$ to the superfusate resulted in an immediate, concentration-dependent increase in the level of CGRP (5-30-fold increase above baseline) in the perfusates, and this effect showed a concentration-dependent tachyphylaxis. [Des-Arg ${ }^{10}$ ]-kallidin, a $B_{1}$ receptor agonist, at concentrations of up to $10^{-4} \mathrm{M}$ did not induce any significant increase in CGRP outflow from the rat trachea. HIS at $10^{-4} \mathrm{M}$ caused a modest but progressive augmentation in the release of CGRP. 5-HT at $10^{-4} \mathrm{M}$ had no effect upon the resting efflux of CGRP, but at a concentration of $10^{-\mathrm{M}} \mathrm{M}$ significantly enhanced the release of CGRP evoked by capsaicin $\left(10^{-6} \mathrm{M}\right)$. Similar conditioning studies carried out with HIS and BK showed no augmentation. BK-evoked CGRP efflux was significantly inhibited by [D-Arg ${ }^{0}$, Hyp $^{3}$, This,8, D-Phe $\left.{ }^{7}\right]-B K\left(B_{2}\right.$ antagonist) and indomethacin. While [Des-Arg', Leu $\left.{ }^{8}\right]-B K\left(B_{1}\right.$ antagonist) also caused a reduction of BK-induced release, its effect did not reach statistical significance. The facilitatory effect of 5-HT on capsaicin-evoked release was not markedly affected by 5-HT, or 5- $\mathrm{HT}_{2}$ antagonists, (s)-(-)propranolol or methysergide, but was totally abolished by the $5-\mathrm{HT}_{3}$ receptor antagonist ICS 205-930 and also by indomethacin. These data suggest that BK, acting through a $B_{2}$ receptor, activates CGRP release from the peripheral terminals of capsaicin-sensitive sensory afferents. The sensitizing effect of 5-HT on the capsaicin-evoked release of CGRP may be mediated via a $5-\mathrm{HT}_{3}$ receptor. Both actions appear to require the formation of cyclooxygenase products for their manifestation.

IKey words: bradykinin, 5-HT, histamine, capsaicin, calcitonin gene-related peptide, release, trachea]

The peripheral terminals of unmyelinated sensory axons are widely distributed. Activation of these terminals is known to influence blood flow, capillary permeability, and local inflam-

\footnotetext{
Received June 10, 1992; revised Nov. 5, 1992; accepted Nov. 11, 1992.

This work was supported by funds provided by the Cigarette and Tobacco Surtax Fund of the State of California through the Tobacco-Related Disease Research Program of the University of California (X.-Y.H.)

Correspondence should be addressed to Xiao-Ying Hua, Department of Anesthesiology 0818, University of California at San Diego, 9500 Gilman Drive, La Jolla, CA 92093-0818.

Copyright (C) 1993 Society for Neuroscience $0270-6474 / 93 / 131947-07 \$ 05.00 / 0$
}

matory cell function (see Szolcsanyi, 1984). The effects are thought to be mediated by the local release of mediators such as the tachykinins and calcitonin gene-related peptide (CGRP) (see Holzer, 1988). The mammalian respiratory tract, including the trachea, is innervated by unmyelinated afferents containing CGRP and, to a lesser extent, substancc $P$ and ncurokinin $A$ (Lundberg et al., 1983; Cadieux et al., 1986). Thus, manipulations that evoke neurogenic inflammatory responses observed in the trachea, for example, an increase in vascular permeability by local application of capsaicin (CAP) (Lundberg and Saria, 1983) or an increase in tracheal blood flow by antidromically electrical stimulation of vagal nerve (see Martling, 1987), may do so by the local release of these peptides.

In previous work, using the intralumenally perfused isolated trachea, we have shown that CAP, excess potassium, or electrical field stimulation will yield an acute stimulus-dependent increase in the extracellular levels of CGRP (Hua and Yaksh, 1992). This release is calcium dependent and can be induced by the local excitation of the TTX-treated axon (Hua and Yaksh, 1991), emphasizing that CGRP and tachykinin activity is released from these tracheal afferents by local terminal depolarization.

It has been shown that local application of a variety of materials typically found in the tissue following local injury can evoke activity in C-fibers. Thus, mast cell degranulation leads to the release of histamine (HIS) and 5-HT as well as other inflammatory mediators (Fewtrell et al., 1982; Schleimer et al., 1986). Activation of the Hageman factor and the initiation of certain Hageman-dependent pathways lead to the formation of BK (Miller and Margolius, 1988). These agents have been shown to evoke sensory C-fiber excitation (Kaufman et al., 1980; Lang et al., 1990). Electrophysiological study of the rat skin has revealed that 5 -HT excited $43 \%$ of the polymodal C-fibers that are also driven by BK and CAP. Furthermore, conditioning treatment with $5-\mathrm{HT}$ caused a sensitization to subsequent BK stimulation (Lang et al., 1990).

Given the correlation outlined above between terminal activity and local release, it follows that pharmacological stimuli known to activate C-fiber terminals may result in the local release of terminal contents. The current thinking regarding the release of CGRP from the afferent terminal suggests that stimuli that lead to the activation of the C-fiber terminal will in fact evoke the exocytotic release of the vesicular contents of the terminal. Thus, studies carried out in guinea pig lung (Saria et al., 1988) or heart (Franco-Cereceda et al., 1989; Geppetti et al., 1991) have shown that, consistent with the stimulatory effect, local application of BK will evoke the subsequent release of the peptides from the peripheral terminals. This measurement of peripheral afferent release thus provides a direct method for 

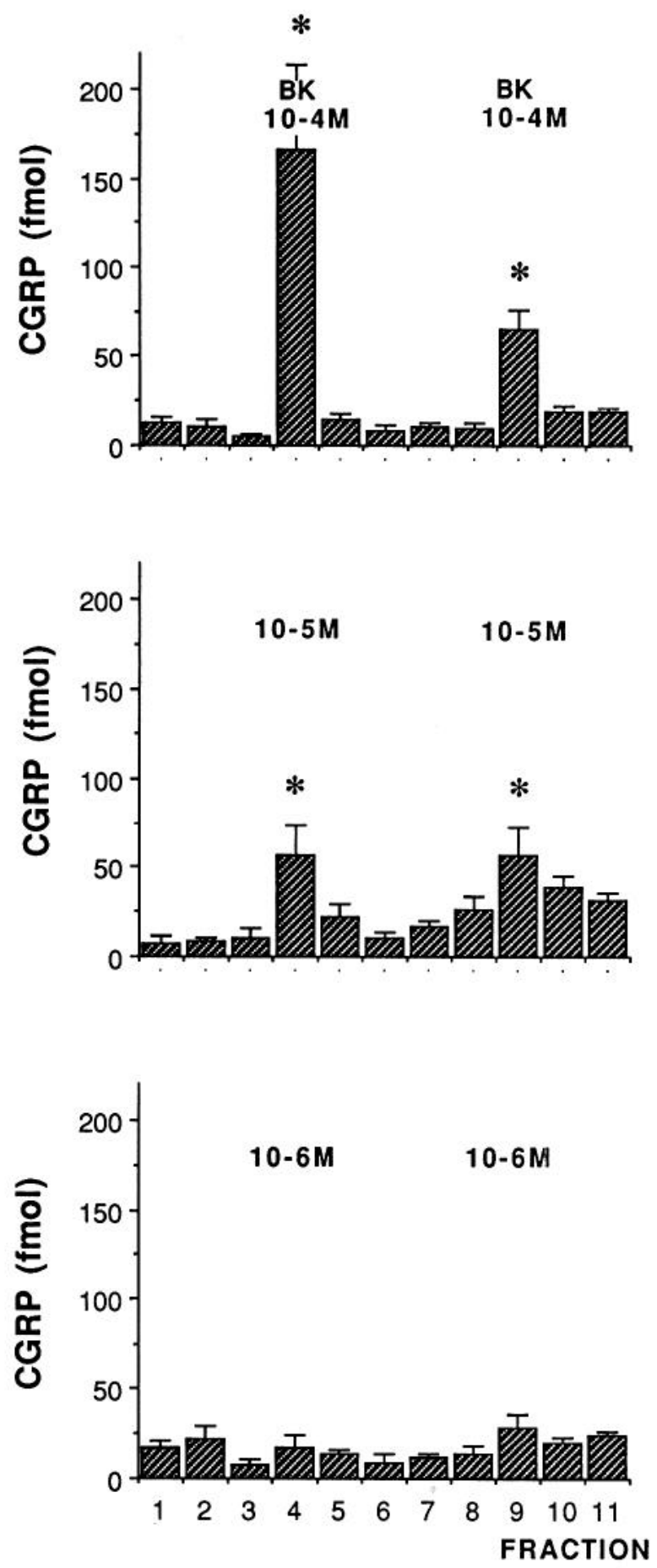

Figure 1. CGRP level (femtomoles per $10 \mathrm{~min}$ sample) in the perfusates from intralumenally perfused rat trachea. BK $\left(10^{-6}\right.$ to $\left.10^{-4} \mathrm{M}\right)$ was applied in fractions 4 and 9 . Each value represents the mean \pm SEM of four or five experiments. ${ }^{*}, P<0.05$ as compared fraction 3 versus 4,8 versus 9 , and 4 versus 9 , by using one-way ANOVA for repeated measurements followed by Dunnett's test.

assessing the local pharmacology of the peripheral terminal. Given the well-defined release of CGRP from C-fibers in the trachea and the known stimulatory effects of several autocoids on vagal afferents, we sought, in the present study, to examine the effects of three inflammatory substances, BK, HIS, and 5-HT, on tracheal afferent CGRP release and to define the receptor pharmacology of their actions.

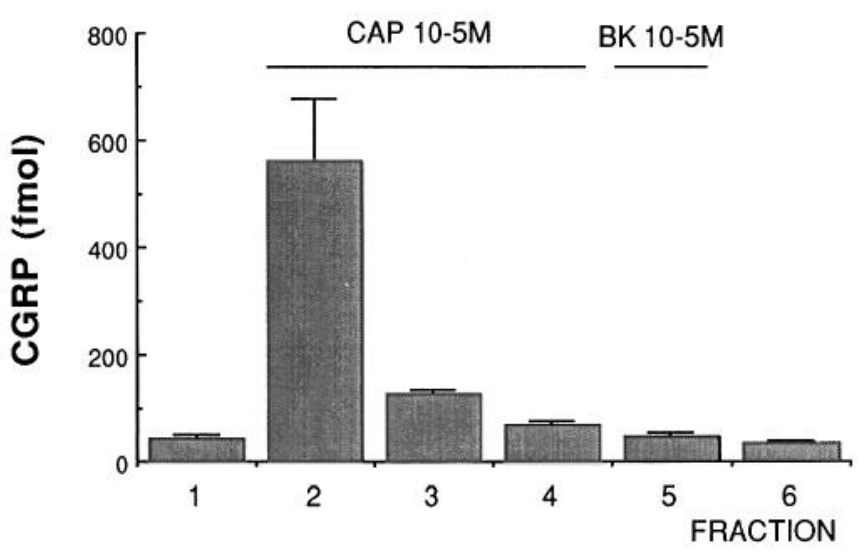

Figure 2. The effect of CAP desensitization on BK-induced CGRP release from perfused rat trachea. CAP at $10^{-5} \mathrm{M}$ was applied at fractions 2,3 , and 4. BK $10^{-5} \mathrm{M}$ was administrated at fraction 5. CGRP level is expressed as femtomoles per $10 \mathrm{~min}$ fraction, and the data are given as mean \pm SEM of five experiments.

\section{Materials and Methods}

Release experiment. Male Sprague-Dawley rats (300-350 gm body weight) were used in the present study. The animals were anesthetized with sodium pentobarbital (Anthony Prod; $50 \mathrm{mg} / \mathrm{kg}$, i.p.) and decapitated. The trachea (from larynx to carina) was carefully removed and placed in a perfusion bath $\left(37^{\circ} \mathrm{C}\right)$. Intralumenal tracheal perfusion was carried out with oxygenated $\left(95 \% \mathrm{O}_{2}, 5 \% \mathrm{CO}_{2}\right)$ Krebs'-bicarbonate solution, which contained (in $\mathrm{mM}$ ) $\mathrm{NaCl}, 118.3 ; \mathrm{KCl}, 4.7 ; \mathrm{CaCl}_{2}, 2.5$; $\mathrm{MgSO}_{4}, 1.2 ; \mathrm{NaHCO}_{3}, 25 ; \mathrm{KH}_{2} \mathrm{PO}_{4}, 1.2$; and, glucose, $11 ; 0.3 \%$ bacitracin added to prevent possible peptide degradation; $\mathrm{pH}$ 7.35-7.45. The perfusion flow rate was $0.2 \mathrm{ml} / \mathrm{min}$. After a $30 \mathrm{~min}$ equilibration period, perfusates $(2 \mathrm{ml})$ were collected at $10 \mathrm{~min}$ intervals in test tubes containing acetic acid (final concentration of $2 \mathrm{M}$ ). To investigate the possible facilitatory effects on CGRP release, BK, 5- HT, and HIS (all given at a concentration of $10^{-6} \mathrm{M}$ ) were added to the perfusate in the sample preceding and during the administration of CAP $\left(10^{-6} \mathrm{M}\right)$. To study the antagonist pharmacology of the effects of two BK analogs, [D-Arg $\left.{ }^{0}, \mathrm{Hyp}^{3}, \mathrm{Thi}^{5,8}, \mathrm{D}-\mathrm{Phe}^{7}\right]-\mathrm{BK}\left(\mathrm{B}_{2}\right)$ (Dray and Perkins, 1988) or [Des$\left.\mathrm{Arg}^{9}, \mathrm{Leu}^{8}\right]$-BK $\left(\mathrm{B}_{1}\right)$ (Regoli et al., 1990), $\left(10^{-6}\right.$ or $5 \times 10^{-6} \mathrm{M}$ ) was applied in the sample $10 \mathrm{~min}$ before and during the application of BK. For 5-HT, the 5-HT antagonists $(s)-(-)$ propranolol $\left(5-\mathrm{HT}_{1}\right)$ (Hide et al., 1989), methysergide (5- $\mathrm{HT}_{2}$ ) (Fozard, 1984), and ICS 205-930 (5$\left.\mathrm{HT}_{3}\right)$ (Eschalier et al., 1989) $\left(10^{-6} \mathrm{M}\right)$ were similarly applied $10 \mathrm{~min}$ before and during the administration of 5-HT. To consider the role of cyclooxygenase products, indomethacin $\left(10^{-5} \mathrm{M}\right)$ was applied $20 \mathrm{~min}$ before and during BK or 5-HT application. To examine the effects of capsaicin desensitization, CAP $\left(10^{-5} \mathrm{M}\right)$ was applied in samples $2-4$ and BK was then applied in sample 5 (see Fig. 2). All fractions were then frozen and lyophilized before radioimmunoassay (RIA).

Radioimmunoassay. CGRP determination was achieved with RIA using CGRP antibody G987 $(1: 84,000)$ and ${ }^{125}$ I-Tyr $^{0}$-CGRP tracer. CGRP antibody G987 is a gift from Dr. H. Heath (Mayo Clinic, MN), and details of the antibody have been reported (Cater et al., 1991). The absolute sensitivity of G987 is $4.0 \mathrm{fmol} /$ assay tube, CGRP antibody G987 is $100 \%$ cross-reactive to rat CGRP, human CGRP- $\alpha$, and human CGRP- $\beta$, but does not cross-react to calcitonin, $\mathrm{CGRP}_{23-37}, \mathrm{CGRP}_{28-37}$, or SP $(<1 \%$ at $1 \mathrm{pmol} /$ tube). In a previous study, we have demonstrated that the immunoreactivity released from the rat trachea detected by antibody G987 was eluted as a single peak at the same fraction as synthetic rat CGRP- $\beta$ (Hua and Yaksh, 1992). CGRP trace was purified by elution from a reverse-phase column using HPLC with an acetonitrile gradient. The assay was carried out in duplicate, and nonspecific binding and blanks were assessed. The peptide levels are expressed as femtomoles per $10 \mathrm{~min}$ fraction. The background blanks were examined in normal Krebs' buffer or buffer containing the substances examined; neither of them interfered with CGRP RIA.

Drugs. We used bradykinin acetate salt (Sigma), 5-hydroxytryptamine hydrochloride (5-HT; Sigma), histamine (Sigma), indomethacin (Sigma), (s)-(-)propranolol (Sigma), methysergide maleate (Sandoz), ICS 205-930 (Sandoz), [Des-Arg ${ }^{10}$ ]-kallidin (a gift from Dr. Eric Whalley, 

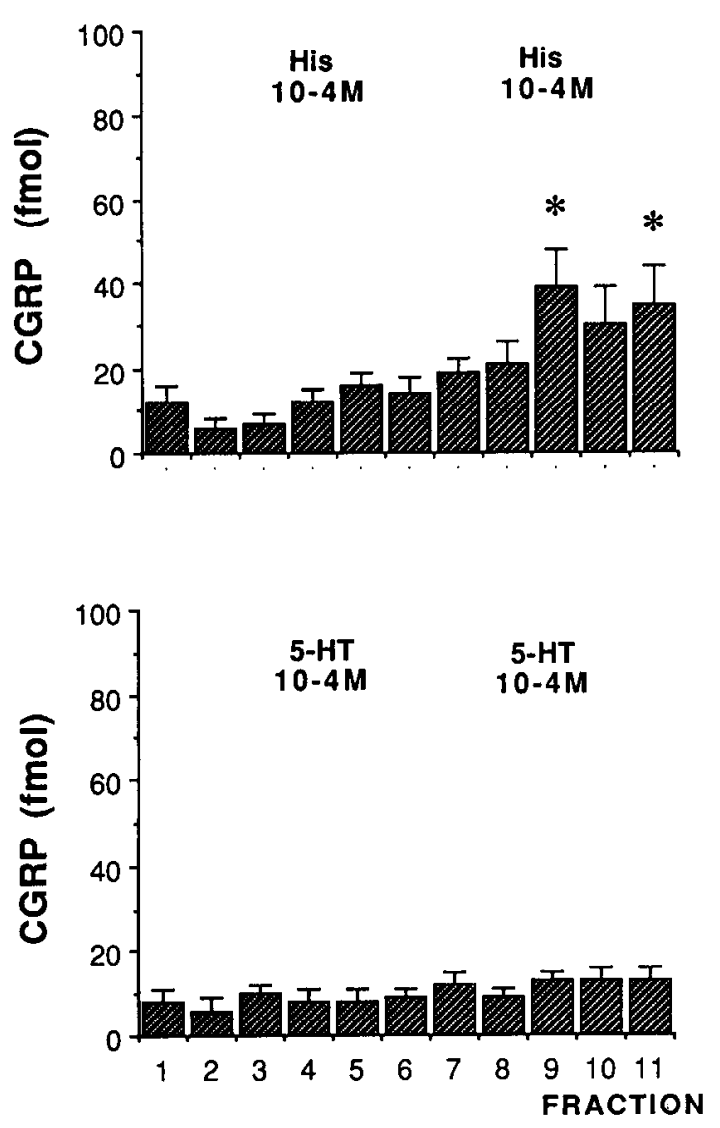

Figure 3. CGRP release (femtomoles per $10 \mathrm{~min}$ fraction) from the perfused rat trachea in the presence of HIS at $10^{-4} \mathrm{M}$ and 5-HT at $10^{4}$ $M$, which were applied to the trachea in samples 4 and 9 . The data are given as mean \pm SEM and represent observations from four experiments. $*, P<0.05$, one-way ANOVA for repeated measurements followed by Dunnett's test.

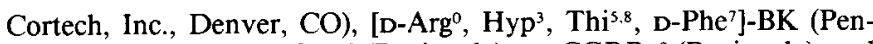
insula), [Des-Arg', Leu ${ }^{8}$ ]-BK (Peninsula), rat CGRP- $\beta$ (Peninsula), and capsaicin (Sigma; purity of 98\%). Capsaicin and indomethacin were initially dissolved in ethanol and subsequently diluted in Krebs' buffer with a final concentration of $0.6-1.0 \%$ ethanol. In previous work, we have shown that this vehicle did not influence the basal release of CGRP (Hua and Yaksh, 1992). The other agents were all dissolved in Krebs' buffer. All agents werc reagent grade.

Data analysis. Statistical significance was calculated using one-way analysis of variance (ANOVA), with multiple comparisons for independent or repeated measurements followed by Dunnell's test. Critical values reaching a $P<0.05$ level were considered significant.

\section{Results}

\section{Basal release of $C G R P$}

In the perfusate from the isolated rat trachea, basal outflow of CGRP was $32 \pm 5 \mathrm{fmol}$ per $10 \mathrm{~min}$ fraction in untreated preparation $(n=30)$ (Figs. $1-4)$. In the absence of pharmacological manipulation, this level remained stable for periods in excess of $1.5 \mathrm{hr}$.

\section{Evoked release of $C G R P$}

Exposure of the rat trachea to BK-containing $\left(10^{-6}\right.$ to $\left.10^{-4} \mathrm{M}\right)$ buffer resulted in a concentration-dependent increase of CGRP level in the perfusates (Fig. 1). Forty minutes after the first application with $\mathrm{BK}$ at $10^{-5} \mathrm{M}$, a second exposure to $\mathrm{BK}$ at the same concentration caused a similar amount of release of CGRP (Fig. 1). The release evoked by a second application of BK at

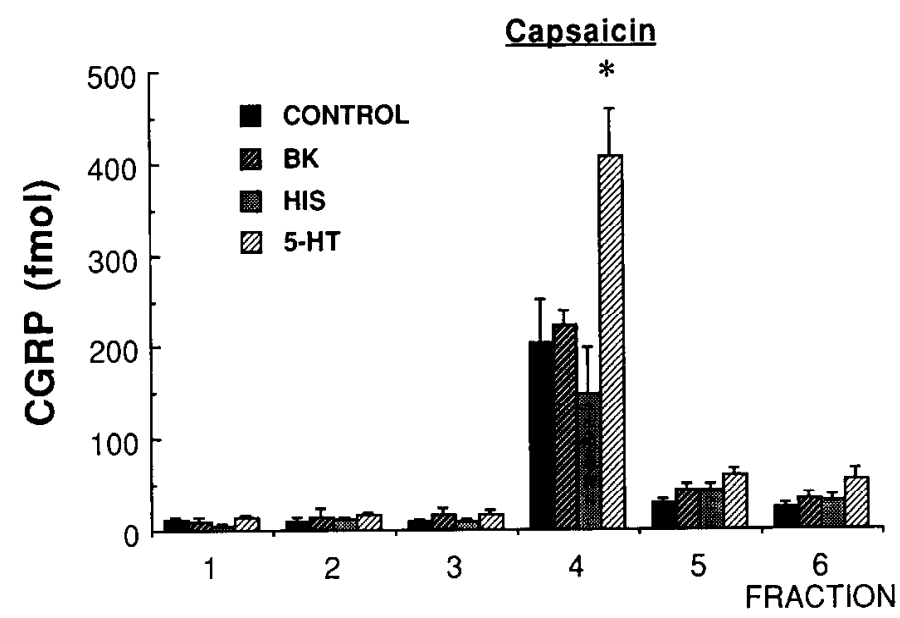

Figure 4. CGRP level (femtomoles per $10 \mathrm{~min}$ fraction) from the isolated rat trachea during the administration of CAP $\left(10^{-6} \mathrm{M}\right)$ alone (CONTROL) in fraction 4 or CAP at the same concentration with conditioning application of BK, HIS, or 5- HT, all at $10^{-6} \mathrm{M}$ in fractions 3 and 4 . The values represent the mean \pm SEM of 7-12 experiments. *, $P<0.05$ as compared with 5-HT group versus control group using oneway ANOVA for independent groups followed by Dunnett's test.

$10^{-4} \mathrm{M}$, however, was significantly diminished as compared to the first exposure $[F(4,50)=5.12, p<0.01]$ (Fig. 1). [DesArg ${ }^{10}$ ]-kallidin, a $B_{1}$ agonist (Regoli et al., 1990), was without effect at $10^{-6} \mathrm{M}$ and $10^{-5} \mathrm{M}$ (data not shown). A modest numerical increase in CGRP was seen at $10^{-4} \mathrm{M}$ (basal, $33 \pm 5.7$ fmol; [Des-Arg ${ }^{10}$ ]-kallidin, $45 \pm 9.9 \mathrm{fmol}$ per $10 \mathrm{~min}$ fraction; $n=6$ ), but this change did not achieve statistical significance. Continued application of CAP at $10^{-5} \mathrm{M}$ for $30 \mathrm{~min}$ evoked an acute release followed by a progressive decline in the subsequent samples to baseline. The subsequent application of BK at $10^{-5}$ $M$ was then without effect (Fig. 2).

5-HT at $10^{-4} \mathrm{M}$ (Fig. 3) and HIS at $10^{-5} \mathrm{M}$ (data not shown) did not cause any change in the efflux of CGRP. HIS at $10^{-4} \mathrm{M}$ induced a modest, gradual increase in CGRP outflow. Following the second application of HIS, there was a pronounced increase in release $[F(3,32)=6.5, p<0.001]$ at the same concentration (Fig. 3).

The addition of a CAP-containing buffer $\left(10^{-6} \mathrm{M}\right)$ induced a remarkable efflux of CGRP from the perfused rat trachea $(\triangle \mathrm{CGRP}=204 \pm 48 \mathrm{fmol}$, basal level of the release subtracted) (Fig. 4). Conditioning application of 5-HT, at a concentration $\left(10^{-6} \mathrm{M}\right)$ that had no effect upon basal release, served to augment prominently the release evoked in the presence of CAP $(\triangle C$ GRP $=405 \pm 53$ fmol) $[F(3,29)=2.88, p<0.05]$ (Fig. 4). CAPinduced peptide release was not altered in the presence of $\mathrm{BK}$ or HIS (Fig. 4).

\section{Bradykinin antagonists}

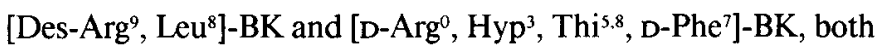
at $10^{-6} \mathbf{M}$, had no effect upon the release evoked by BK $(5 \times$ $10^{-6}$ M) (Fig. 5). [D-Arg $\left.{ }^{0}, \mathrm{Hyp}^{3}, \mathrm{Thi}^{5,8}, \mathrm{D}-\mathrm{Phe}^{7}\right]-\mathrm{BK}$ at a concentration of $5 \times 10^{-6} \mathrm{M}$ caused a significant reduction in the increased CGRP release induced by BK $[F(5,35)=3.16, p<$ 0.05] (Fig. 5). [D-Arg ${ }^{0}, \mathrm{Hyp}^{3}$, Thi $\left.{ }^{5,8}, \mathrm{D}-\mathrm{Phe}^{7}\right]-\mathrm{BK}$ at $5 \times 10^{-6} \mathrm{M}$ served to enhance CGRP release in two out of six experiments. [Des-Arg $\left.{ }^{9}, \mathrm{Leu}^{8}\right]-\mathrm{BK}$ at a concentration of $5 \times 10^{-6} \mathrm{M}$ also caused a reduction of BK-induced CGRP release; it did not, however, reach a statistical significance. Indomethacin at $10^{-5}$ 


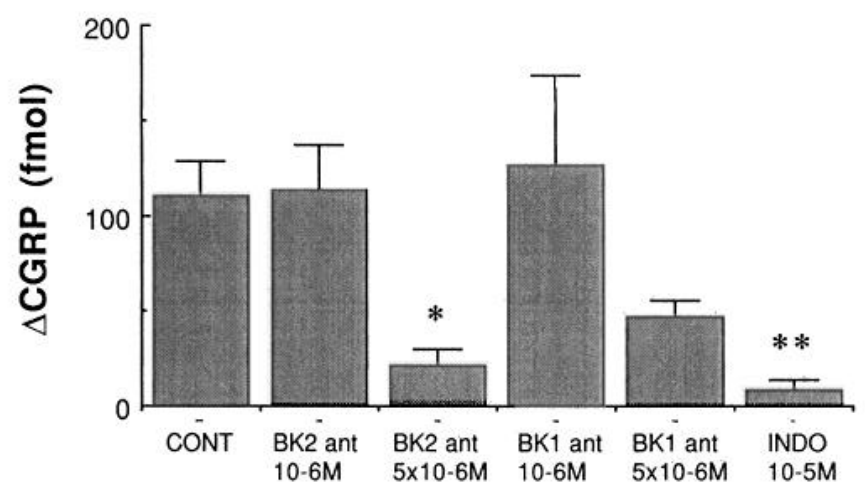

Figure 5. The evoked CGRP release ( $\triangle$ CGRP, femtomoles per $10 \mathrm{~min}$ fraction, the basal level of CGRP subtracted) by BK $\left(5 \times 10^{-6} \mathrm{M}\right)$ alone (CONT, control) or by pre-administration of [D-Arg ${ }^{0}, \mathrm{Hyp}^{3}, \mathrm{Thi}^{5,8}$, D-Phe ${ }^{7}$-BK (B2 ant), [Des-Arg ${ }^{9}$, Leu $^{8}$ ]-BK (BI ant), or indomethacin $(I N D O))^{*}, P<0.05$ as compared with control group versus [D-Arg, $\mathrm{Hyp}^{3}$, Thi ${ }^{5.8}, \mathrm{D}-\mathrm{Phe} \mathrm{P}^{7}$-BK $\left(B 2\right.$ ant, $\left.5 \times 10^{-6} \mathrm{M}\right){ }^{* *}, P<0.01$, control group versus indomethacin group; one-way ANOVA for independent measurements followed by Dunnett's test $(N=4-8)$.

M almost completely abolished the increase in CGRP outflow by $\mathrm{BK}[F(5,35)=3.84, p<0.01]$ (Fig. 5).

\section{5-HT antagonists}

The basal level of CGRP efflux from the rat trachea was not influenced in the presence of $10^{-6} \mathrm{M}(s)$-(-)propranolol, methysergide, or ICS $205-930$, or $10^{-5} \mathrm{M}$ indomethacin (data not shown). (s)-(-)Propranolol and methysergide caused a reduction of 5-HT-induced $\left(10^{-6} \mathrm{M}\right)$ enhancement of CGRP release by CAP $\left(10^{-6} \mathrm{M}\right)$ to some extent, but these differences are not statistically significant. In contrast, ICS $205-930\left(10^{-6} \mathrm{M}\right)[F(4,31)$ $=4.16, p<0.01]$, as well as indomethacin $\left(10^{-5} \mathrm{M}\right)[F(4,31)=$ $3.25, p<0.05]$, induced a pronounced inhibition of the sensitization effect of 5-HT effect on the CGRP release evoked by BK (Fig. 6).

\section{Discussion}

In the present study, CGRP levels in the perfusates from isolated rat trachea were elevated by $\mathrm{BK}$ and the CAP-evoked release was augmented by 5 -HT. Previous studies have shown that CGRP is contained in vagal afferent C-fibers and these stores have been shown to be CAP sensitive (Cadieux et al., 1986). Immunohistochemical studies have demonstrated that, in addition to primary sensory nerve fibers, modest amounts of CGRP immunoreactivity exist in endocrine-like cells in the epithelium of the rat trachea (Shimosegawa and Said, 1991). We do not believe these cells contribute to the present evoked release because (1) these cells appear to be CAP resistant (Shimosegawa and Said, 1991), and (2) the preliminary result has shown that tracheal CGRP release still exists after stripping of the epithelium (M. Hogman and X.-Y. Hua, unpublished observations). These observations and the observation from the present study that BK did not induce any release in the CAP-desensitized trachea thus suggest that the peptide response to these inflammatory agents reflects an action on the afferent terminal, which is ultimately reflected in the release of CGRP. The issues relevant to the several autocoids will be considered below.

\section{Bradykinin}

In the present study, we observed that local application of BK to the inner lumen of the rat trachea induced a concentration-

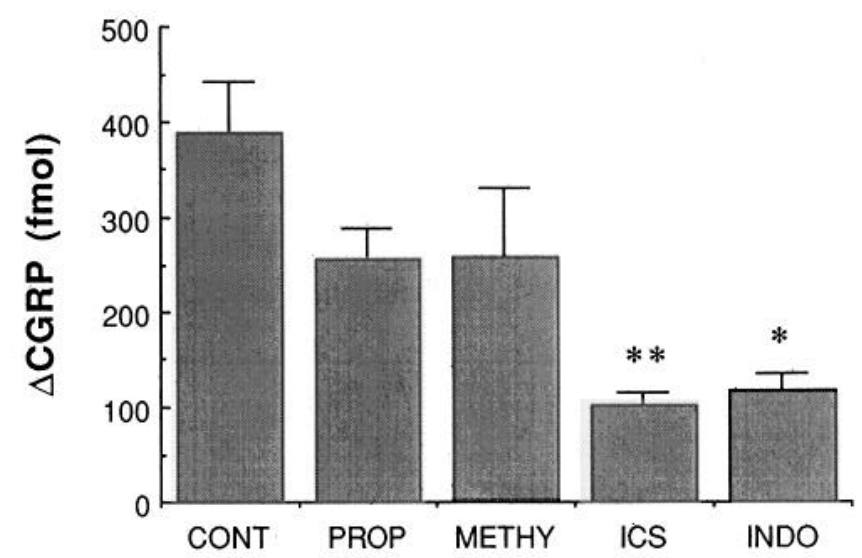

Figure 6. The effects of 5-HT antagonists $(s)-(-)$ propranolol (PROP; $10^{-6} \mathrm{M}$ ), methysergide (METHY;10 $\left.0^{-6} \mathrm{M}\right)$, and ICS 205-930 (ICS; $10^{-6}$ $\mathrm{M})$, and indomethacin $\left(I N D O ; 10^{-5} \mathrm{M}\right)$ on the enhancement of CAPevoked $\left(10^{-6} \mathrm{M}\right)$ CGRP release by 5 -HT $\left(10^{-6} \mathrm{M}\right)(\mathrm{CONT}$, control). $\triangle$ CGRP: the evoked release in femtomoles per 10 min collection, with the baseline of the release subtracted. ${ }^{* *}, P<0.01$, control group versus ICS 205-930; *, $P<0.05$, control group versus indomethacin group; one-way ANOVA for independent groups followed by Dunnett's test. The data are given as mean \pm SEM and represent observations from $7-12$ experiments.

dependent release of CGRP, which was indomethacin sensitive. This result is consistent with previous work indicating that many of the actions of BK on smooth muscle and in activating the peripheral terminal of primary sensory neurons are mediated by the release of prostaglandins (PGs) (see Regoli et al., 1990). Importantly, $\mathrm{BK}$ will in fact stimulate $\mathrm{PGE}_{2}$ release from human (Churchill et al., 1989) and canine tracheal epithelial cells (Leikauf et al., 1985), $\mathrm{PGI}_{2}$ from the guinea pig heart (Geppetti et al., 1991), and cultured endothelial cells from the bovine aorta (Hock et al., 1991). In the airway, $\mathrm{PGE}_{1}, \mathrm{PGE}_{2}$, and $\mathrm{PGF}_{2 \alpha}$ have been found to activate afferent C-fibers (Coleridge et al., 1976) and to facilitate vascular permeability induced by CAP (Saria and Lundberg, 1984). In other work, we have found that $\mathrm{PGE}_{1}$, $\mathrm{PGE}_{2}, \mathrm{PGF}_{2 \alpha}$, and $\mathrm{PGI}_{2}$ are all able to induce CGRP release from the CAP-sensitive afferent in the rat trachea, and this release is not altered by pretreatment with indomethacin (X.Y. Hua et al., unpublished observations).

The observation that repeated application of BK resulted in a subsequent diminution of the amount of CGRP released, with the degree of reduction proportional to the first exposure concentration, is consistent with other studies with this peptide. Thus, in rat saphenous nerve preparation, half of the BK-sensitive C-fibers did not respond to a second BK stimulus. This desensitization could not be reversed by the application of 100 fold higher BK concentration or by a 1.5-hr washout period (Lang et al., 1990). The mechanism of this inactivation is not clear. However, McGehee and colleagues in their recent study (McGehee et al., 1992) have provided evidence suggesting that the nitric oxide-cyclic GMP pathway is involved in BK desensitization in rat dorsal root ganglion cells.

With regard to the pharmacology of the BK effect, BK and related kinins exert their biological effects by activating at least two different receptor types: $\mathrm{B}_{1}$ and $\mathrm{B}_{2}$ (see Regoli et al., 1990). The $\mathrm{BK}$ receptor mediating the nociceptor response to $\mathrm{BK}$ is believed to have the pharmacological characteristics of the $\mathrm{B}_{2}$ subtype (Dray and Perkins, 1988; Mizumura et al., 1990). Furthermore, electrophysiological studies have provided evidence 
that a $B_{1}$-preferring agonist was unable to evoke activity in nociceptors (Mizumura et al., 1990). Moreover, the $B_{2}$, but not $\mathbf{B}_{1}$, antagonist displayed an inhibitory effect on nociceptive responses to BK (Dray and Perkins, 1988). In the present study, two specific observations were made. First, only the BK, and not the $\mathrm{B}_{1}$ agonist [Des-Arg ${ }^{10}$ ]-kallidin, could evoke CGRP release. Second, this $B K$-evoked peptide release was significantly suppressed by the $\mathrm{B}_{2}$ antagonist [D-Arg ${ }^{0}, \mathrm{Hyp}^{3}$, Thi $\left.{ }^{5,8}, \mathrm{D}-\mathrm{Phe}^{7}\right]-$ $\mathrm{BK}$, but not by the $\mathrm{B}_{1}$ antagonist [Des-Arg9 ${ }^{9} \mathrm{Leu}^{8}$ ]-BK. These results jointly support the hypothesis that $\mathrm{BK}$ activates CGRP release from the peripheral terminals of CAP-sensitive sensory afferent through a $\mathrm{B}_{2}$ receptor. Significantly, [D-Arg ${ }^{0}, \mathrm{Hyp}^{3}$, $\mathrm{Thi}^{5,8}$, D-Phe ${ }^{7}$-BK induced approximately an $80 \%$ reduction of CGRP release at a concentration of $5 \times 10^{-6} \mathrm{M}$. This value is essentially identical to the $\mathrm{pA}_{2}$ value obtained in guinea pig taenia caeci ( $\mathrm{pA}_{2}$ is about 5.5) (Field et al., 1988) and in guinea pig ileum $\left(\mathrm{pA}_{2}=6.0\right)$ (Steranka et al., 1989). This agent does, however, appear to be more potent in the rat uterus $\left(\mathrm{pA}_{2}=6.9\right)$ (Steranka et al., 1989). [Des-Arg9, Leu ${ }^{8}$ ]-BK, which is known to have a relatively low affinity for the $\mathrm{B}_{2}$ receptor $\left(\mathrm{pD}_{2}<5.0\right)$, displayed a potent antagonistic effect on the rabbit aorta: a pure $B_{1}$ receptor system $\left(\mathrm{pA}_{2}=7.27\right.$ ) (see Regoli et al., 1990). It has been reported that prostanoid synthesis activated by $\mathrm{BK}$ may also be mediated via a $B_{2}$ receptor (Hock et al., 1991; Neppl et al., 1991). Based on antagonist analysis, in the guinea pig trachea, BK-induced, $\mathrm{PG}$-dependent relaxation appeared not to involve activation of either $a B_{1}$ or $B_{2}$ site (Rhaleb et al., 1988). A possible species difference, consistent with other $\mathrm{BK}$ receptor types, must be considered (Regoli et al., 1990).

Autoradiographic studies have revealed BK binding sites to be found in small dorsal root ganglion cells, and in high concentrations in regions of the dorsal horn to which primary afferents project and in the periphery (Steranka et al., 1988). While these binding data suggest that the BK sites may be on the central and peripheral terminals of CAP-sensitive primary afferents, it is not clear that CGRP released by $B K$ is via a receptor located on the terminal. The certainty of a direct effect is called into question by observations that (1) the BK effect is mediated through the release of PGs (see above), and (2) sympathetic neurons may be involved in BK-induced hyperalgesia and inflammation (Levine et al., 1986; Taiwo and Levine, 1988; Lee et al., 1991).

\section{Histamine and 5-HT}

HIS and 5-HT have been reported to be able to excite certain limited populations of polymodal C-fiber afferents (see Handwerker, 1990). 5-HT- and HIS-evoked increases in vascular permeability in the airway are absent in the animal pretreated with CAP (Lundberg and Saria, 1983), suggesting a possible stimulatory effect upon the C-fiber terminal. In the present study, however, 5-HT did not exert any direct excitatory effect on CGRP release, and HIS displayed some modest activity at high concentrations. The modest action might emphasize that HIS and 5-HT are rapidly taken up and metabolized or that they interact with axons that do not secrete CGRP. As will be noted below for 5-HT, this does not appear to be the case.

\section{5-HT receptor}

Previous studies have emphasized that the action of 5-HT on the peripheral terminal of primary sensory afferents is mediated by a receptor having characteristics resembling those of a $5-\mathrm{HT}_{3}$ receptor (Higashi and Nishi, 1982; Round and Wallis, 1985; Eschalier et al., 1989). For example, 5-HT evokes depolarization of primary afferents in rabbit nodose ganglion that is blocked in a competitive fashion by ICS 205-930 (Round and Wallis, 1985) but not by methysergide (Higashi and Nishi, 1982). Both 5-HT and 5- $\mathrm{HT}_{3}$ agonist 2-methyl-5-HT caused a painful effect when applied to a blister base of human forearm. ICS 205-930 in the nanomolar range blocked both 5-HT-evoked and 5-HTpotentiated nociceptive effects by BK in human blister (Richardson et al., 1985). ICS 205-930 also blocked carrageenaninduced hyperalgesia in rats (Eschalier et al., 1989), which also suggests the endogenous release of 5-HT as well as its involvement in the sensitization of peripheral nociceptors and the role of the $5-\mathrm{HT}_{3}$ receptor. Comparable results were observed in the present study. Thus, among the 5-HT antagonists examined, only ICS $205-930\left(5-\mathrm{HT}_{3}\right.$ antagonist), and not $(s)-(-)$ propranolol or methysergide (5-HT, and/or 5-HT ${ }_{2}$ antagonists), blocked the facilitatory effect of 5-HT on the CAP-evoked release of CGRP from the trachea. A putative $5-\mathrm{HT}_{4}$ receptor has been recently proposed (Dumuis et al., 1988; Clarke et al., 1989), on which ICS 205-930 in the micromolar range is reported to function as an antagonist (Villalon et al., 1990, 1991). Thus, we should not exclude the possibility of either or both a $5-\mathrm{HT}_{3}$ and a $5-\mathrm{HT}_{4}$ receptor in the trachea.

\section{Afferent terminal sensitization}

Both BK and 5-HT are also well known for their ability to sensitize the nociceptor (Lang et al., 1990; see Basbaum, 1991). This facilitation of BK, however, has been proposed by an action on an intermediate system, such as the sympathetic terminal, to release some substances which in turn results in facilitation (Levine et al., 1986; Taiwo and Levine, 1988). Our present observations reveal that only 5-HT, and not BK or HIS, enhanced CGRP release from the rat trachea induced by CAP. These observations are in accord with other studies (see Handwerker, 1990; Lang et al., 1990) that indicate that 5-HIT shows a more reliable sensitizing effect than other mediators, such as norepinephrine or $\mathrm{PGE}_{2}$.

\section{The possible role of prostanoids}

The fact that both the effects of BK stimulation and 5-HT enhancement of CGRP release were blocked by indomethacin suggests that prostanoid production is involved in both the stimulatory and facilitatory actions on the nerve terminal. Two issues are emphasized. First, because each agent behaves differentially, that is, BK evokes release but does not sensitize while 5-HT sensitizes but does not evoke, it seems probable that different elements of the cyclooxygenase cascade must be involved in the actions of the respective agents. Second, at present it is not clear from what source the cyclooxygenase products are derived. PGs sensitize a majority of the C-polymodal afferents (Martin et al., 1987) and potentiate the vascular permeability increase induced by CAP (Saria and Lundberg, 1984). In the preliminary study, however, no PGs examined $\left(\mathrm{PGE}_{1}, \mathrm{PGE}_{2}\right.$, $\mathrm{PGF}_{2 \alpha}, \mathrm{PGI}_{2}$ ) showed sensitizing activity on CAP-evoked peptide release from the rat trachea, although all displayed direct excitatory effects in the same model (Hua et al., unpublished observations). Instability of thromboxane $A_{2}$ prevents the investigation of the biological activity of this agent. Interestingly, a stable $\mathrm{PGI}_{2}$ analog, carba-PGI $\mathrm{P}_{2}$, has been reported to enhance CAP-evoked release of substance $P$ and CGRP from rat sensory neuron (Hingtgen and Vasko, 1992). Further work employing 
selective competitive receptor antagonists and stable agonists for the several prostanoids is required.

In summary, the present studies have emphasized that autocoids, which arc rclcased following local injury and inflammation, are able to stimulate or sensitize the terminals of C-fibers and then evoke or facilitate the local secretion of CGRP from those terminals. The well-defined effects of CGRP during neurogenic inflammation suggest that this local activation may serve a complex role not only to provide the afferent information necessary for generating centrally mediated responses, but also to provide a local trophic regulation.

\section{References}

Basbaum A (1991) Peripheral mechanisms of sensitization and hyperalgesia. In: Anesthesiology and pain management (Stanley TH, Ashburn MA, Fine PG, eds), pp 31-37. Boston: Kluwer Academic.

Cadieux A, Springall DR, Mulderry PK, Rodrigo J, Chatei MA, Terenghi G, Bloom SR, Polak JM (1986) Occurrence, distribution and ontogeny of CGRP immunoreactivity in the rat lower respiratory tract: effect of capsaicin treatment and surgical denervation. Neuroscience 19:605-627.

Cater WB, Taylor RL, Kao PC, Heath H (1991) Determination of plasma calcitonin gene-related peptide concentration by a new immunochemiluminometric assay in normal persons and patients with medullary thyroid carcinoma and other neuroendocrine tumors. J Clin Endocrinol Metab 72:327-335.

Churchill L, Chilton FH, Resau JH, Bascom R, Hubbard WC, Proud D (1989) Cyclooxygenase metabolism of endogenous arachidonic acid by cultured human tracheal epithelial cells. Am Rev Respir Dis 140:449-459.

Clarke DE, Craig DA, Fozard JR (1989) The 5-HT4 receptor: naughty, but nice. Trends Pharmacol Sci 10:385-386.

Coleridge HM, Coleridge JCG, Ginzel KH, Baker DG, Banzett RB, Morrison MA (1976) Stimulation of 'irritant' receptors and afferent C-fibers in the lungs by prostaglandins. Nature 264:451-453.

Dray A, Perkins MN (1988) Bradykinin activates peripheral capsaicinsensitive fibers via a second messenger system. Agents Actions 25: 214-215.

Dumuis A, Bouhelal R, Sebben M, Bockaert J (1988) A 5-HT receptor in the central nervous system, positively coupled with adenylatecyclase, is antagonized by ICS 205-930. Eur J Pharmacol 146:187188.

Eschalier A, Kayser V, Guilbaud G (1989) Influence of a specific 5-HT3 antagonist on carrageenan-induced hyperalgesia in rats. Pain 36:249-255.

Fewtrell CMS, Foreman JC, Jordan CC, Oehme P, Renner M, Stewart JM (1982) The effects of substance $P$ on histamine and 5-HT release in the rat. J Physiol (Lond) 330:393-411.

Field JL, Fox AJ, Hall JM, Magbagbeola AO, Morton IKM (1988) Multiple bradykinin B2 receptor subtypes in smooth muscle preparation. Br J Pharmacol 93:284P.

Fozard JR (1984) Neuronal 5-HT receptors in the periphery. Neuropharmacology 23:1473-1486.

Franco-Cereceda A, Saria A, Lundberg JM (1989) Differential release of calcitonin gene-related peptide and neuropeptide $Y$ from the isolated heart by capsaicin, ischaemia, nicotine, bradykinin and ouabain. Acta Physiol Scand 135:173-187.

Geppetti P, Bianco ED, Tramontana M, Vigano T, folco GC, Maggi CA, Manzini S, Fanciullacci M (1991) Arachidonic acid and bradykinin share a common pathway to release neuropeptide from capsaicin-sensitive sensory nerve fibers of the guinea-pig heart. J Pharmacol Exp Ther 259:759-765.

Handwerker HO (1990) What peripheral mechanisms contribute to nociceptive transmission and hyperalgesia? In: Towards a new pharmacotherapy of pain (Basbaum AI, Besson JM, eds), pp 5-20. New York: Wiley.

Hide I, Kato T, Yamawaki S (1989) In vivo determination of 5 -hydroxytrytramine receptor-stimulated phosphoinositide turnover in rat brain. $\mathrm{J}$ Neurochem 53:556-560.

Higashi H, Nishi S (1982) 5-Hydroxytryptamine receptors of visceral primary afferent neurons on rabbit nodose ganglia. J Physiol (Lond) 323:543-567.
Hingtgen CM, Vasko MR (1992) Carba prostacyclin potentiates capsaicin-stimulated release of neuropeptides from rat sensory neurons in culture. Soc Neurosci Abstr 18:691.

Hock FJ, Wirth K, Albus U, Linz W, Gerhards HJ, Wiemer G, Henke S, Breipohl G, Konig W, Knolle J, Scholkens BA (1991) Hoe 140, a new potent and long acting bradykinin-antagonist: in vitro studies. Br J Pharmacol 102:769-773.

Holzer P (1988) Local effector functions of capsaicin-sensitive sensory nerve endings: involvement of tachykinins, calcitonin gene-related peptide and other neuropeptides. Neurosciencee 24:739-768.

Hua X-Y, Yaksh TL (1991) The effect of electrical field stimulation and inflammatory substances on the release of CGRP from the rat trachea. Soc Neurosci Abstr 17:398.

Hua X-Y, Yaksh TL (1992) Release of calcitonin gene-related peptide and tachykinins from the rat trachea. Peptides 13:113-120.

Kaufman MP, Coleridge HM, Coleridge JCG, Baker DG (1980) Bradykinin stimulates afferent vagal C-fibers in intrapulmonary airways of dog. J Appl Physiol 48:511-517.

Lang E, Novak A, Keeh PW, Handwerker HO (1990) Chemosensitivity of fine afferents from rat skin in vitro. J Neurophysiol 63:887901.

Lee A, Coderre TJ, Basbaum AI, Levine JD (1991) Sympathetic neuron factors involved in bradykinin-induced plasma extravasation in the rat. Brain Res 557:146-148.

Leikauf GD, Ueki IF, Nadel JA, Widdicombe JH (1985) Bradykinin stimulates $\mathrm{CL}$ secretion and prostaglandin $\mathrm{E} 2$ release by canine tracheal epithelium. Am J Physiol 248:F48-F55.

Levine JD, Taiwo YO, Collins SD, Tam JK (1986) Noradrenaline hyperalgesia is mediated through interaction with sympathetic postganglionic neurone terminals rather than activation of primary afferent nociceptors. Nature 323:158-160.

Lundberg JM, Saria L (1983) Capsaicin-induced desensitization of airway mucosa to cigarette smoke, mechanical and chemical irritants. Nature 302:251-253.

Lundberg JM, Brodin E, Saria A (1983) Effects and distribution of vagal capsaicin sensitive substance $P$ neurons with special reference to the trachea and lungs. Acta Physiol Scand 119:243-253.

Martin HA, Basbaum AI, Kwiat GC, Goetzl EJ, I evine JD (1987) Leukotrine and prostaglandin sensitization of cutaneous high-threshold C- and A-delta mechanociceptors in the hairy skin of rat hindlimbs. Neuroscience 22:651-659.

Martling (1987) Sensory nerves containing tachykinins and CGRP in the lower airways. Acta Physiol Scand 130[Suppl 563]:1-57.

McGehee DS, Guy MF, Oxford GS (1992) Involvement of the nitric oxide-cyclic GMP pathway in the desensitization of bradykinin responses of cultured rat sensory neurons. Neuron 9:315-324.

Miller DM, Margolius HS (1988) Kallikrein-kininogen-kinin system. In: Endocrinology, Vol 3, 2d ed (DeGroot LJ, Cahill GF Jr, eds), pp 2491-2503. Orlando, FL: Grune \& Stratton.

Mizumura K, Minagawa M, Tsujii Y, Kumazawa T (1990) The effects of bradykinin agonists and antagonists on visceral polymodal receptor activities. Pain 40:221-227.

Neppl H, Neuhof H, Afflerbach F, Llach Puig Neppl J, Berghofer A (1991) Bradykinin-induced oedema formation proceeds from B2 receptor stimulation and is potentiated by concomitantly released prostaglandins. Acta Physiol Scand 142:141-147.

Regoli D, Rhaleb N-E, Dion S, Drapeau G (1990) New selective bradykinin receptor antagonists and bradykinin $\mathrm{B} 2$ receptor characterization. Trends Pharmacol Sci 11:156-161.

Rhaleb N-E, Dion S, D'Orleans-Juste P, Drapeau G, Regoli D, Browne $R G$ (1988) Bradykinin antagonism: differentiation between peptide antagonists and antiinflammatory agents. Eur J Pharmacol 151:275279.

Richardson BP, Engel G, Donatsh P, Stadler PA (1985) Identification of serotonin M-receptor subtypes and their specific blockade by a new class of drugs. Nature 316:126-131.

Round A, Wallis DI (1985) Selected blockade by ICS 205-930 of 5-HT depolarization of rabbit vagal afferent and sympathetic ganglion cells. Br J Pharmacol 86:734P.

Saria A, Lundberg JM (1984) Activation of sensory substance P neurons in the respiratory tract by cigarette smoke, mechanical and chemical irritants. Front Horm Res 12:123-126.

Saria A, Martling C-R, Yan Z, Theodorsson-Norheim E, Gamse R, Lundberg JM (1988) Release of multiple tachykinins from capsaicin-sensitive sensory nerves in the lung by bradykinin, histamine, 
dimethylphenyl piperazinium and vagal nerve stimulation. Am Rev Respir Dis 137:1330-1335.

Schleimer RP, Macglashan DW Jr, Peters SP, Pinckard RN, Adkinson NF Jr, Lichtenstein LM (1986) Characterization of inflammatory mediator release from purified human lung mast cells. Am Rev Respir Dis 133:614-617.

Shimosegawa T, Said SI (1991) Pulmonary calcitonin gene-related peptide immunoreactivity: nerve-endocrine cell interrelationships. Am J Respir Cell Mol Biol 4:126-134.

Steranka LR, Manning DC, DeHaas CJ, Ferkany JW, Borosky SA, Connor JR, Vavrek RJ, Stewart JM, Snyder SH (1988) Bradykinin as a pain mediator: receptors are localized to sensory neurons, and antagonists have analgesic actions. Proc Natl Acad Sci USA 85:32453249.

Steranka LR, Farmer SG, Burch RM (1989) Antagonists of B2 bradykinin receptors. FASEB J 3:2019-2025.
Szolcsanyi J (1984) Capsaicin-sensitive chemoceptive neural system with dual sensory efferent function. In: Antidromic vasodilatation and neurogenic inflammation (Chahl LA, Szolcsanyi J, Lembeck F, eds), pp 28-53. Budapest: Akademiai Kiado.

Taiwo YO, Levine JD (1988) Characterization of the arachidonic acid metabolites mediating bradykinin and noradrenaline hyperalgesia. Brain Res 458:402-406.

Villalon CM, der Boer MO, Heiligers PC, Saxena P (1990) Mediation of 5-hydroxytryptamine-induced tachycardia in the pig by the putative 5-HT4 receptor. Br J Pharmacol 100:665-667.

Villalon CM, der Boer MO, Heiligers PC, Saxena P (1991) Further characterization, by use of tryptamine and benzamide derivatives, of putative 5-HT4 receptor mediating tachycardia in the pig. $\mathrm{Br} \mathrm{J}$ Pharmacol 102:107-112. 